\title{
Itinerarium Egeriae: A Retrospective Look and Preliminary Study of a New Approach to the Issue of Authorship-provenance
}

\author{
Víctor Parra-Guinaldo
}

American University of Sharjah, Sharjah, United Arab Emirates

Copyright $\mathrm{O} 2019$ by authors, all rights reserved. Authors agree that this article remains permanently open access under the terms of the Creative Commons Attribution License 4.0 International License

\begin{abstract}
One of the most controversial questions with respect to the Itinerarium Egeriae is its author's provenance, and whether this can be determined on linguistic grounds. The purpose of this paper is twofold: 1) to provide a central synopsis and account of previous relevant work that has been conducted on the manuscript; and 2) address one of the most contested and controversial questions with respect to whether its origin can be determined on linguistic grounds. In this paper, I revisit this conundrum by addressing two major flaws I find in the methodology employed to date: 1) the Romanisms sought after are for the most part only either hispanisms or gallicisms; and 2) the scrutiny of the data is not rigorous enough, since these are usually selected merely on the basis of lexical resemblance with modern reflexes, disregarding the fact that many of these may not even qualify as regionalisms in the first place. I resolve this problem by following Adams's (2007) shrinkage theory, where the only plausible regionalisms are innovations, namely those terms that can only be found in texts later than the Classical period; but I disagree with his view on Egeria's provenance as the problem would remain inconclusive, and I demonstrate that there is compelling evidence for an Iberian origin.
\end{abstract}

Keywords Itinerarium Egeriae, Peregrinatio Etheriae, Shrinkage, Vulgar Latin, Hispanism

\section{Introduction and Purpose}

Since Gamurrini's editio princeps of 1887, the publications dealing with the Itinerarium Egeriae ${ }^{1}$ (hence

1 Since there is no record of the original title, I adopt here the most commonly accepted title of the Itinerarium Egeriae, although other titles, such as the Peregrinatio Aetheriae have also been prevalent in past decades.
It. Eg.), the travelog of a pilgrim to the Holy Land (Starowleyski 1979), number in the hundreds. Some of these, such as Fonda (1966) and Maraval (1982), provide an excellent overview of the different aspects traditionally discussed about the text. The twofold purpose of this paper is: 1) to provide a central synopsis of an updated ${ }^{2}$ account of previous work in three areas that are relevant to this paper, namely, the discovery of the manuscript, the date in which it was originally written, and the provenance of the author; and 2) address one of the most contested and controversial questions with respect to the It. Eg.: whether the origin of the author can be determined on linguistic grounds. I will revisit this conundrum by addressing a major flaw I find in how the methodology employed to date has been applied, namely the search for regionalisms that may reveal writing of a particular geographical area, with the final intent of offering further evidence towards a Spanish origin. I then propose and demonstrate a new methodological approach, following Adams's (2007) concept of shrinkage though disagreeing with his concluding remarks about Egeria's provenance. I then suggest that two more points of interest in favor of a Spanish origin be closely considered in future studies before recapitulating some of the more important issues dealt with in this essay.

\section{Discovery and Date of the Text}

The It. Eg. was discovered by the Italian historian and archeologist Gian Francesco Gamurrini in 1884 in the library of the Brotherhood of St. Mary, also known by the name of Pia Fraternità dei Laici, at Arezzo, Italy (Fonda 1966, Wilson-Kastner et al. 1981). The It. Eg., as it

2 Some of the seminal works, such as Löfstedt (1911), are dated, and understandably exclude later findings, whereas some of the more recent publications are not as comprehensive. 
appeared to Gamurrini, was part of what today we know as Codex Aretinus 405 (Dietz 2005) and before as Codex Aretinus VI, 3 (Fonda 1966). This codex had been brought to Arezzo from the Abbey of Montecassino, where the manuscript had probably been copied under the direction of Abbot Desiderio and then registered in a catalog of $1532^{3}$. Today the Codex is currently housed in the Arezzo City Library (Fonda 1966). Gamurrini claimed in his edition that the author of the Codex must have been St. Silvia of Aquitaine, based on the Sancti Hilarii Tractatus; but the It. $E g$. is a different text altogether, only to be included in the Codex while in Montecassino. The date and the authorship of the It. Eg. has since become challenging enigmas. The It. $E g$. itself is divided into two parts of similar length: the first one, chapters I through XXIII, is a travelog in which the author describes her pilgrimage to the loca sancta in the Holy Land, starting with her visit to Mount Sinai and ending with her arrival at Constantinople ${ }^{4}$; the second one, chapters XXIV through XLIX, is an account of the liturgical services the author attended while in Jerusalem (Wilson-Kastner et al. 1981).

Although some pieces of information with respect to the It. Eg. is unclear or unknown, the date it was written seems to have been determined. Gamurrini was quite accurate when he estimated that the travelog must have taken place sometime between 381 and 388 (Wilson-Kastner et al. 1981). Meister (1909) claimed though that the ecclesiastical life described corresponded rather to the sixth century. Some Benedictine scholars have preferred the fifth century (Dietz 2005). Two major historical events seem to have determined both the terminus a quo and the terminus ad quem in relation to the accounts narrated in the It. Eg.: the former is year 363, when Nisibis became inaccessible to the Romans after it fell into Persian control; the latter is year 540, when the Persians destroyed Antioch under the command of Chosroes ${ }^{5}$ (Dietz 2005, Wilkinson 1981). Likewise, since Egeria had been able to pay a few visits to Antioch, as she indicates several times, her journey can only have taken place before the established terminus ad quem of 540. Finally in 1967, Paul Devos was able to, if not ascertain at least, provide the most probable and accurate dates of the narrated journey's beginning and end, namely between 381 and 384 . He based his calculation on two pieces of information: a list of Syrian bishops, and the dates on which Easter was celebrated ${ }^{6}$.

3 For information about how Codex Aretinus 405 was transferred from Montecassino to the Fraternity of St. Mary, see Augusto Campana, "La storia della scoperta del Codice Aretino nel Carteggio Gamurrini-De Rossi," in Atti del Convegno Internazionale sulla Pereginatio Egeriae, nel centenaio della pubblicazione del Codex Aretinus 405 (già Aretinus VI, 3), ed. Accademia Petrarca Di Lettere Arti E Scienze (Arezzo 1990), 77-84: $81 \mathrm{ff}$.

4 For a detailed list of the loca sancta visited by Egeria, see Speake 2003. $5 \mathrm{I}$ am using here the Greek version of his name following Wilkinson (1981), but this ruler is also known by any of these Persian names: Khusro, Khosrau, Khusrau, Khosro, or Khusraw.

6 See Devos 1967 for details.

\section{Egeria's Provenance}

One of the most controversial aspects with respect to the It. Eg. is its author's provenance. As mentioned above, the pages that probably contained the information about the author and the date in which the manuscript was written are missing; therefore one cannot easily ascertain where the author came from. Most scholars have opted for either a French or a Spanish origin, or to use terms contemporary to the It. Eg., Gaul or Aquitaine if French, Galicia if Spanish ${ }^{7}$. Other regions of the Empire are usually not considered, since there are contextual references that would make these hard to justify. For example, there is a passage where the bishop praises Egeria's undertaking having come from "the far extreme of the earth:"

XIX, 5 [...] suspiciens me ait michi: "Quoniam uideo te, filia, gratia religionis tam magnum laborem tibi imposuisse, ut de extreme porro terris uenires ad haec loca, itaque ergo, hic grata ad uidendum Christianis, ostendimus tibi."

[...] and who had hospitably received me, said to me: "My daughter, I see that you have taken on yourself, because of your piety, the great task of journeying from very distant lands to these places. Therefore, if you are willing, we will show you whatever places there are here that Christians like to see."

From this it has been claimed that Egeria could only have started her journey somewhere along the Atlantic coast, whether France or Spain.

Coincidentally, Valerius uses similar words in his letter, when he praises Egeria's journey to the Holy Land:

[1b] Qua extremo occidui maris oceani litore exorta, Orienti facta est cognita.

Who, having risen from the farthest shore of the ocean, the Western sea, was made known in the East. ${ }^{8}$

Férotin (1903) was the first one to assume a Spanish origin due to Valerius's words. It is also interesting to notice, as Dietz (2005) has pointed out, that Egeria was but one of various Galicians to have traveled to the Holy Land around the same time frame, namely the end of the fourth century and beginning of the fifth century, and she names for example Hydatius, bishop of Iria Flavia; Orosius, who interestingly enough indicates that his homeland is on the Atlantic coast; Avitus of Braga, an adjoining town to modern Galicia; and Bachiarius, a Spanish monk.

On the other hand, based on a particular passage in the It. $E g$. or on a particular lexical term ${ }^{9}$, Sivan (1988) proposed

7 Gaul, also known as Gallia in Roman times, roughly occupied the northern half of modern France, whereas Aquitaine, or Aquitania in Latin, the southern half. After the tenth century, Aquitania became known as Occitania. Galicia is situated in modern north-western Spain.

8 Paul Arena provided help with the translation of this sentence.

9 See Sivan (1988) and Weber (1989) for details. 
Arles, France, and Weber (1989) preferred Mont-Saint-Michel, also in France. The passage in question reads:

XVIII, 2 Itaque ergo proficiscens in quintodecimo miliario in nomine Dei perueni ad fluuium Eufratem, de quo satis bene scriptum est esse flumen magnum Eufraten et ingens, et quasi terribilis est; ita enim decurrit habens impetum sicut habet Rodanus, nisiquod maior est Eufrates.

After having travelled fifteen miles from Hierapolis, in the name of God, I arrived at the river Euphrates, which Scripture very well described as the great river Euphrates. It is large and rather frightening, for it flows with as swift a current as the river Rhone, except that the Euphrates is much larger.

Here, Egeria is comparing the Rodanus, or the Rhône River as it is known in modern times, with the Euphrates River, which has led some scholars to conclude that, since she was familiar with this French river, she must have come from at least a neighboring area. But it seems to me that Egeria could have familiarized herself with this French river on her way through; furthermore, if she was originally from Galicia, it only makes sense that she would have compared the Euphrates with the only large river she had encountered on her way to the Holy Land. The only rivers she would have known from home, the Duero and the Ebro, probably did not deserve comparison with the Euphrates, since they are not nearly as swift.

\section{Research Question}

The external evidence, namely the interpretations drawn from the content of the It. Eg., as well as secondary sources such as Valerius's letter, seem to suggest that the author of the travelog may have come from the north-west of the Iberian Peninsula, known as Callaecia or Gallaecia in Roman times, and approximately comprising today's Galicia, León, and Asturias in Spain and northern Portugal. These interpretations though may be construed as mere conjectures about the text and may not provide a conclusive answer to the question about the pilgrim's provenance. However, the most useful clues may be hidden within the language used by Egeria. These clues could constitute internal evidence that would provide, if not conclusive, at least plausible grounds for establishing the author's origin.

It was mentioned before that the original manuscript must have been written between the years 381 and 384, according to Devos's calculations (1967). The Latin used in the Roman Empire around these years is of particular interest to historical linguists, since this language can be said to be transitioning from Classical Latin to the earliest stages of the different Romance languages we know today: Italian, French, Spanish, Portuguese, and Romanian, to name just a few of the major ones. Traditionally, this Latin in transition has received the name of Vulgar Latin, although several other terms have been suggested in order to avoid the easily misinterpreted meaning of Vulgar ${ }^{10}$. Oftentimes, Vulgar Latin has been equated with spoken Latin, and although it would be hard to claim that there is any one text exclusively written in Vulgar Latin, the statement oversimplifies the probable linguistic scenario: Classical Latin is the source for Christian Latin on the one hand, but over time for Literary Castilian on the other; spoken Latin instead became spoken Castilian, but spoken Latin may also have influenced the written language of different genres, although in different degrees ${ }^{11}$. But note also Herman's (1967) assertion that Vulgar Latin and spoken Latin are not the same thing, and that "there never was an unbridgeable gap between the written and spoken languages."

The research question of this study, therefore, is: Did Vulgar Latin provide localisms that would somehow differentiate the linguistic variety employed in a particular region, for example that of Aquitaine, from that of another, for example that of the north-west of the Iberian Peninsula?

Those following Muller (1929) and in support of the thèse unitaire ${ }^{12}$ or 'the unitarian argument' (Adams 2007) would argue that there were no perceivable differences across the various regions of the Empire, as attested by the linguistic homogeneity present in the vast collection of literary records over the centuries in the Classic and post-Classic periods. Then, a period of punctuation or sudden differentiation would ensue, in which the, until then, fairly uniform language would split into linguistic variants rather abruptly ${ }^{13}$. Adams (2007) is in disagreement with this view and claims that there existed diatopic variation not only during the Empire, but also within its preceding period, the Republic. In his study, Adams provides extensive evidence from a variety of texts to justify his claim.

The question about localisms or regionalisms in Vulgar Latin can now be reformulated once we contemplate Adams's claim for a regional diversification of Latin, as the title of his extensive study suggests. Since the language of the It. Eg. is rich in non-classical usages, will it then be possible to determine what variety of Latin Egeria was using in her travelog and from this, to conclude the provenance of the author? I will try to show in the present study that this is in fact the case.

Previous Research on Egeria's Language

The content of the It. Eg. reveals details about Egeria's journey in the Holy Land, which are of interest to

10 For an insight on this subject, see Väänänen 1968, p. 25

11 Pountain (2001, pp. 7-11) provides a clear synopsis of the probable evolution of Latin into the various Romance languages.

12 See also Väänänen (1983)

13 I mention here Dixon's (1997) punctuation of equilibrium situation as a possible explanation of what could have happened to Classical Latin in accordance to the proposed thèse unitaire. 
theologians and philologists alike. Similarly, the content has been considered in making claims about the time frame in which the pilgrimage was carried out, and even about the social and religious status of this fourth-century pilgrim. Secondary sources, such as library catalogs and Valerius's letter, attest the existence of an original manuscript and may also provide insight about the author herself with different degrees of credibility.

The language style employed in the travelog has also attracted a lot of attention. Latinists or Classicists tend to interpret Egeria's repetitions, long stretches, pleonasms and anacolutha (Fonda 1966) as "unusual" or even "deplorable by Classical standards" (Spitzer 1949). Also, Egeria's unexpected case agreements, altered verb inflections or a new use of prepositions have oftentimes been viewed as mistakes. These scholars fail to realize that it is these anomalies in particular that are the real indicators of a language in transition, the elements that evince the forces of linguistic change in action. Others, however, propose the analysis of the text as what it actually is, a travelog or an autobiography, rather than a piece of literature (Väänänen 1985, McIntosh 1989). Only thus, one can comprehend that Egeria wrote as she talked (Väänänen 1985 ) or that her style was sermo cotidianus or sermo humilis (Fonda 1966).

There is a considerable number of linguistic studies on the language of the It. Eg. Starowleyski (1979) lists about 50 works dealing with linguistic aspects as diverse as the following: Bastiaensen's (1962) overview of the liturgical vocabulary; Ernout's (1954) and Milani's (1969) compilation of Greek terms; the use of in eo loco analyzed by Ambrosini (1955). In addition to this list, Weber (1989) dedicated a whole article to try to demonstrate how a single word, namely tumbae, can be the key to the origin of the author, which he places in Mont St. Michel, in Normandy, France. Ernout (1954) paid special attention to non-classical terms and usages, whereas Spitzer (1949) dealt with the use and function of ipse, which, along with ille, some view as the precursor of the Romance determiner ${ }^{14}$; as for Spitzer, it only indicates the epic patterns of her writing. Following the footsteps of van Oorde (1930), Swanson (1966-67) offers, three decades later, one of the most comprehensive analyses of the vocabulary employed by Egeria in her travelog. He points out that previous works by Bechtel, Anglade and Löfstedt dealt primarily with "orthographic habits" and their "phonological implications," and that they "fully handled" the syntax, but they failed to dedicate the deserved attention to the vocabulary, which motivated him to embark on the classification and analysis of the latter. Thus, Spitzer lists the whole lexicon into derived and underived categories, and offers comments about morpho-phonemics,

14 According to Spitzer (1949), Löftstedt, Wölfflin and Meister follow this view. semantics, underlying stems, innovations, and distributions.

For the most part, the linguistic studies listed above either merely classify and categorize the data or they treat them as manifested evidence of Late Latin in direct contrast to the orthodox practices of Classical Latin, but other than tangential remarks about the possible regional variety they are dealing with ${ }^{15}$, they do not attempt to determine the possible origin of the author. Other scholars, however, have ascribed to one or another origin: Wotke contemplates the possibility of either Aquitaine or Galicia; others such as Vaccari or Meister favor Gaul; yet others such as Geyer, Férotin, Leclerq, García or Petré are more inclined towards Galicia. These scholars usually rely on lists of hispanisms and gallicisms, such as those compiled by Anglade (1905), Tovar (1964) or Álvarez Huerta (2003). A major puzzling complication these scholars have always encountered is the argument that supports a Spanish origin based on the use of hispanisms can also be used to support a French origin based on gallicisms. Löfstedt (1959), among others ${ }^{16}$, came to the conclusion that it is not possible to establish with certainty the homeland of Egeria based on linguistic grounds, and Väänänen (1985) admits that philologists have given up on the idea of looking for hispanisms or gallicisms as their foundation for their arguments.

\section{Methodological Assumptions}

As has been established in previous sections, commentaries about the content in Egeria's travelog are insufficient to determine the provenance of Egeria; furthermore, the classification and categorization of the lexicon employed in the It. Eg. per se can only hint at the dissimilitude between Late Latin and Classical Latin; finally, mere lists of hispanisms and gallicisms seem to point in two directions at the same, making the puzzle of provenance inconclusive.

The approach I take for the present study is historico-linguistic, and the method I adopt is comparative in nature, although the aim is not to reconstruct proto-forms of unknown Late Latin or early Romance lexicon as the comparative method ought to do in its strictest sense (Rankin 2005), but as I mentioned above, to demonstrate that the type of Latin used by Egeria is the one that would have been used in the north-west of the Iberian Peninsula. With this in mind, listing possible hispanisms or gallicisms is not satisfactory enough; instead, a close analysis of the reflexes produced by the selected Latin terms is crucial to determine if indeed we are dealing with hispanisms or

15 An exception to this generalization is McIntosh (1989), who suggests that the Latin in the It. Eg. may have been the one once spoken in the north-west of Spain.

16 Klein (1958) is of the same view as Löfstedt. 
gallicisms in the first place. Many of the purported regionalisms in the It. Eg. has been rejected by Adams (2007) on the grounds of what he terms shrinkage. By this he refers to "a word or usage that was once current in all or many varieties of Latin and it fell out of use in most places and remained current in just one or two, during the passage of Latin to Romance." In the present study I consider Adams's concept of shrinkage, since it reduces the scrutiny of possible regionalisms considerably and allows for a more accurate analysis of the data.

Against Löfstedt's words of discouragement about establishing Egeria's provenance on linguistic grounds, Álvarez Huerta (2003) is more hopeful: "Sobre la lengua de Egeria, en este punto, seguro que todavía hoy no se ha dicho la última palabra;" and she admits being inspired by Väänänen's more recent work, and words: "peut-être, n'a't'on pas encoré dit le dernier mot" (Väänänen 1985) ${ }^{17}$.

There have been indeed numerous attempts to provide a list of selected terms from the It. Eg. and their corresponding Romance reflexes, and although the results seem always to be inconclusive, the fact that the number of purported hispanisms is considerably larger than that of the purported gallicisms is noteworthy. However, this methodology is flawed in two fundamental ways: 1) the Romanisms sought after are for the most part only either hispanisms or gallicisms, ${ }^{18}$ and 2) the scrutiny of the data is not rigorous enough, since these are usually selected merely on the basis of lexical resemblance with modern reflexes, disregarding the fact that many of these may not even qualify as regionalisms in the first place.

If we are right to suppose that Egeria's homeland was somewhere on the Atlantic coast, and as it seems most plausible, from the north-west of the Iberian Peninsula or from Aquitaine, providing reflexes not only of present-day Spanish or French, but also of the linguistic varieties original to these areas, would provide most interesting results. If Egeria was from the north-west of the Iberian Peninsula, one should expect to find reflexes not only in present-day Spanish, but also, and in particular, in Galician, Portuguese, Leonese, and Asturian; and not only in the present state of these languages, but also, and in particular, in as early a stage as is possible to find them. Likewise, one should look for reflexes not only in present-day French, but also, and in particular, in Occitan, and in the earlier stages of both. For the purpose of the present study, since more attention is placed on the second of the aforementioned methodological flaws, I have decided simply to provide a small sample of purported hispanisms with their corresponding reflexes in present-day French (PD.Fr), and where possible, in Old French (O.Fr); then in Occitan

17 Both Álvarez Huerta's and Väänänen's quotations roughly translate as: "As far as Egeria's language, perhaps we have not said it all."

18 Sometimes reflexes from Italian or even Romanian have been offered. I have decided to disregard those since all indications point towards the west of the continent.
(Occ), Galician (Gal), Portuguese (Port), and present-day Spanish (PD.Sp), and where possible in Old Spanish $(\mathrm{O} . \mathrm{Sp})^{19}$. The only purpose of this list is to exemplify the process that ought to be followed, and not to provide an exhaustive analysis of the typically alleged hispanisms. As mentioned above, there exist already several publications presenting more complete lists of hispanisms.

Following the short list of hispanisms ${ }^{20}$, I will tackle the second aspect, namely data scrutiny. For this, I will follow Adams's (2007) concept of shrinkage, and consequently I will pay close attention to the only terms he accepts as possible hispanisms and gallicisms. Finally, I conclude by summarizing the principal ideas that ought to be drawn from this essay.

\section{Data Analysis: Hispanisms}

The following list is divided according to parts of speech, which exemplify Latin terms that show continuity in PD.Sp, and not in PD.Fr, in the form of reflexes. Although these terms are all attested in Classical Latin, some have either a new meaning or a higher frequency of use in the It. Eg. This is indicated in each entry. Special attention should be paid to the reflexes these Latin terms have.

\section{Nouns}

\section{latus Classical Latin}

II. 1. Vallis autem ipsa ingens est ualde, iacens subter latus montis Dei, $[\ldots]$

This valley is certainly vast, extending to the slope of the mountain of God.

O.Fr ${ }^{21}$ : coste (feminine noun) (XII c.); PD.Fr: côté (masculine noun); Gal, Port, O.Sp: lado (1219)

\section{caput Classical Latin}

IV. 6. Propterea autem ad caput ipsius vallis exire nos necesse erat, $[\ldots]$

We had to come out at the head of the valley for this reason as well, [...]

O.Fr: cap (1260), teste (1080); PD.Fr: tête; Occ: cap; Gal: cabeza, testa; Port: cabeça; O.Sp: cabeza;

\section{parietem Classical Latin}

III. 1. [...] sed totum ad directum subis ac si per

19 Please refer to the References page for a list of dictionaries used in the search for reflexes in these languages: Greimas (1997) and Hindley \& Levy (2000) for Old French, and Rodríguez González (1980) for Galego. Also, two concordances, Blackman \& Betts (1989) and Magallón García (1993), have been used to facilitate the cross-reference of the examples provided.

20 A more accurate term should be proposed for a bank of reflexes from an area covering northern Portugal, as well as Galicia, Asturias, and León. 21 O.Fr (Old French), PD.Fr (present-day French), Occ (Occitan), Gal (Galician or Galego), Port (Portuguese), O.Sp (Old Spanish), PD.Sp (present-day Spanish). 
parietem $[\ldots]$

[...] but you go straight up all the way as if scaling a wall $[\ldots]$

O.Fr: paroit, paroi (1080), mur; PD.Fr: mur, paroi (specialized meaning); Gal: parede, muro; Port: parede, muro; O.Sp: parete (1043); PD.Sp: pared

Verbs

subeo, subire Classical Latin, but its new general meaning 'climb' was only a specialized one in Classical times. The verb commonly meant 'go under' or 'approach.'

XI. 4. [...] ita tamen ut pars eius maxima sedendo in asellis posit subiri;

[...] the greater part could be climbed by donkey,

PD.Fr: monter (intr.), lever (tr.); Gal: subir, sober; Port: subir; O.Sp: subir/sober (Cid); PD.Sp: subir

stabamus Classical Latin

III. 8. [...] quia de eo loco ubi stabamus, id est in giro parietes ecclesiae, $[\ldots]$

[...] that we were standing around the enclosure of the church [...]

PD.Fr: nous étions; Port: estábamos; PD.Sp: estábamos

plicauimus Classical Latin, but its only meaning was 'fold,' not 'approach' as in the It. Eg.

VI. 3. [...], ac sic ergo denuo plicauimus nos ad mare.

And once again we approached the sea.

PD.Fr: arriver; Gal, Port: chegar; PD.Sp: llegar

tenebamus Classical Latin, but with a new meaning of 'possess' rather than 'hold.'

VII. 8. [...], ad quae singula uidenda necesse nos fuit ibi descendere iuxta consuetudinem, quam tenebamus.

In accord with the custom which we observed, we made it a point to dismount there to visit each place.

O.Fr: tenir; PD.Fr: avoir; Occ: aver; Gal, Port: ter; PD.Sp: tener

Adjectives

cata Greek borrowing, but employed in Classical Latin.

VII. 2. [...], ut cata mansiones monasteria sint cum militibus et praepositis, [...]

$[\ldots]$, each resting station has a military outpost with soldiers and officers [...]

PD.Fr: chaque; Occ, Gal, Port, O.Sp: cada

\section{Adverbs}

magis Classical Latin, but with a higher frequency of use in the It. Eg.

XIII. 1 [...] fecerunt magis desiderium imponendi michi laboris, ut etiam usque ad illa loca accederem, [...]

[...] they stirred in me a great desire to take upon myself the trouble of going there, [...]

O.Fr: mais, meis, mai, ma, mes (980); PD.Fr: plus; Occ: mai; Gal, Port: mais; O.Sp: maes; PD.Sp: más

nunquam Classical Latin

XIX. 7. [...], quales ego adhuc nunquam uidi, [...]

[...] such as I had never seen before, [...]

O.Fr: nonc, nonque, nonques (842), jamais; PD.Fr: jamais; Occ: jamai, ara, encara; Gal: nunca, xamais; Port: nunca, jamais; PD.Sp: nunca, jamás

tunc Classical Latin

III. 7. [...], tunc cepi eos rogare, ut ostenderent nobis singular loca.

[...], then, [...] I asked them to show us each place.

PD.Fr: alors, dès lors; Occ: alavetz, alara; Gal: entón;

Port: então; O.Sp: entonz (1250), estonces (Cid); PD.Sp: entonces

adhuc Classical Latin

IV. 5. [...], et adhuc nobis superabant milia tria, [...]

[...] and we still had three miles to go [...]

PD.Fr: encore; Occ: pr'aquó; Gal: ainda, inda; Port: ainda; O.Sp: ahú (Cid); PD.Sp: aún

Prepositions

cum Classical Latin

XIII. 2. Itaque ergo profecta sum de Ierusolima cum sanctis, $[\ldots]$

I set out from Jerusalem in the company of holy men, […]

PD.Fr: avec; Occ: amb; Gal: con; Port: com; PD.Sp: con

\section{Tentative Corollary about the Data}

A more complete and accurate description of all possible reflexes in all these languages would be desirable, but it is easy to see that some of the alleged hispanisms presented here are in fact not so, since some of the reflexes in Occitan or Old French also show a direct correspondence with the Latin terms. However, it must be significant considering the fact that when only present-day languages are observed, the correspondences tend to be found only in the languages of the Iberian Peninsula. This issue remains to be studied more closely.

\section{Shrinkage as a Determinant of Data Scrutiny}

Adams (2007) claims that many of the alleged Romanisms in the It. Eg., namely hispanisms and 
gallicisms, cannot be established only on the basis of reflexes in Spanish or French. In other words, the fact that, for example, French does not have a reflex of a Latin word does not mean that it did not at an earlier stage. We saw before that Latin nunquam evolved into Spanish nunca; this could then be construed as a hispanism based on the fact the Latin term has a reflex in Spanish, but not in French, this corresponding word being jamais. However, Old French had nonc, nonque, nonques, which proves that Latin nunquam has also rendered a French reflex. Therefore, one should also consider the intermediate stages of the languages under scrutiny.

Thus, he rejects as valid hispanisms or gallicisms those terms that were common at one point in the Republic or the Empire, but fell out of use in almost all regions but one or two. He gives cras as an example of a word that was commonplace across the Empire, but only remained in use to the present day in Sardinian. In Adams's words, cras went through a process of shrinkage in those other regions where cras was replaced by mañana in Spanish and demain in French. The same logic applies to the It. Eg. For example, a word like caput 'head' should not be considered a hispanism based on the fact that its corresponding word in present-day French is tête, since Old French indeed had a direct reflex from Latin caput, namely cap, as indicated above under the heading 'Hispanisms.'

So long as we use Classical Latin terms, we ought to assume the possibility that there may have been reflexes of such terms in the earlier stages of the daughter languages, whether we have extant records of these or not. Therefore, Adams rejects expressions such as tam magnus, secunda feria, and fui ad ecclesiam, which have traditionally been viewed as hispanisms, as well as alleged gallicisms, such as manduco and sera, since these are all expressions in common use during the Classic period and, consequently, they all may have had reflexes in the early stages of both French and Spanish.

In order to find possible regionalisms, it is desirable, according to Adams (2007), that we only consider innovations, namely those terms that can only be found in texts later than the Classical period. Only in this way, we could be sure that the terms we are dealing with are particular to a specific region. Thus, the only two terms Adams accepts as probable regionalisms in the It. Eg. are plicare and pullus. The former is, according to him, a hispanism, whereas the latter a gallicism. They are both lexical items not present in Classical Latin, but they were in Vulgar Latin, that is new creations in the areas they originated. The hispanism plicare has not been recorded in any text from Gaul, and the gallicism pullus has not been recorded in any text in Hispania. It could be concluded that, once more, we have run against the same problem we started out with: Egeria may have come from either the Iberian Peninsula or somewhere in France. Adams (2007) finds the answer somewhere on middle ground; he "tentatively attribute[s the provenance of the text to] the territory spanning the Gallo-Iberian border." This view seems to run counter to the idea that Egeria came from the most extreme end of the continent, or at least it seems to be a new ad hoc location based only on convenience.

What makes pullus a gallicism, Adams (2007) claims, is not that this term was not used in the Iberian Peninsula at the time of Vulgar Latin, but that it did not have the meaning of 'rooster' in the It. Eg. as it did in Old French (since $c o q$ is the term used in present-day French). The word pullus is indeed attested in early records in the Spanish language, although referring to a small animal, usually a small fowl, but also to a young donkey (Corominas 1954). In fact, the Spanish reflex pollo is a very common word referring both to the 'young bird,' but also to the 'chicken' that it is eaten, regardless of its gender. It is possible, I claim, that the sense Egeria used for pullus in her travelog was maintained in the Iberian Peninsula until much later before it went through a process of semantic shift.

Indeed, semantic changes are a common process. Spanish yegua $<$ Latin equa is an example of this. Through specialization, a lexical item that referred to both male and female, equus/-a 'horse/mare,' has become nowadays the term that refers to only the female yegua 'mare', whereas a new term was introduced in Vulgar Latin to refer to the male, caballus, which in turn used to mean 'pack-horse,' this time by means of the opposite process, broadening (Trask 2000). Thus, if a Latin term such as equus/a changed in meaning in the Iberian Peninsula, it is not implausible to see how the use of pullus as a rooster could also have been present here at one time. Furthermore, Bynon ([1977] 1996) depicts the distribution of pullus (with the meaning of 'young rooster'), in contrast to gallus and other dialectal varieties in France, in the form of isoglosses, and the restricted region where pullus is used happens to be the southern-most, next to the Iberian Peninsula, and coincidentally, roughly corresponding to the Occitan region. It should be noticed that Occitan shares more reflexes with Spanish than French, as exemplified above.

Ultimately, the region where Egeria's homeland is to be found can be said to have been reduced to an area stretching from the southern-most of present-day France, or Occitain, to the north-west of Spain. Consequently, if we accept that it is possible that pullus was also part of the vocabulary of the northern part of the Iberian Peninsula, it would not be unreasonable to claim that this region was Egeria's homeland. 


\section{Conclusions ${ }^{22}$}

I hope to have shown here the two major ways scholars have failed to reach a conclusive answer as to the provenance of the author of the It. Eg. based on lists of hispanisms and gallicisms. In the first place, they usually disregard linguistic varieties that should be deemed relevant to a more accurate description of Romance reflexives; secondly, they fail to discriminate between innovations in Vulgar Latin, which are better candidates for true regionalisms, and terms already present in Classical Latin, which may have gone through a process of shrinkage, in accordance with Adams (2007). Finally, I have suggested that the distribution of verb conjugations in the Latin of the It. Eg. be considered more seriously; and that the borrowing of alleged gallicisms is easily justifiable, whereas that of hispanisms is not.

\section{REFERENCES}

[1] Adams, J. N. 2007. The regional diversification of Latin 200 BC - AD 600. Cambridge: C.U.P

[2] Álvarez Huerta, O. 2003. Sobre los hispanismos en el Itinerarium Egeriae. In H. Solin (Ed.), Latin vulgaire, latin tardif: Actes du VI colloque international sur le latin vulgaire et tardif, (pp. 83-97). Helsinki: Hildesheim.

[3] Ambrosini, R. 1955. Il tipo sintagmatico "in eo loco" e questioni di principio nello studio della Peregrinatio Aetheriae. Annali della Scuola Normale Superiore di Pisa, 2 (24), 97-109.

[4] Anglade, J. 1905. De latinitate libelli qui inscriptvs est "Peregrinatio ad loca sancta." Bordeaux-Paris: A. Fontemoing, Bibliopolam [Dissertation].

[5] Bastiaensen, A. A. R. 1962. Observations sur le vocabulaire liturgique dans l'Itinéraire d'Egérie. Nijmegen: Latinitas Christianorum Primaeva 17.

[6] Blackman, D. R., and Betts, G. G. (Eds.). 1989. Concordantia in Itinerarium Egeriae: A concordance to the Itinerarium Egeriae. Hildesheim; New York: Olms-Weidmann.

[7] Bruyne, D. de. 1909. Nouveaux fragments de l'Itinerarium

22 Additional Comments in Favor of a Spanish Homeland: It is well known (see for example Grandget (2002) and Herman (1967) among others ) that in Vulgar Latin the second and third conjugation of verbs suffered changes that affected the Romance languages in different ways. Spain turned most of these into second conjugation verbs, whereas French and Italian favored the third and fourth conjugations over the second. Although Grandget (2002) briefly mentions that the second conjugation is predominant over the third, this is a fact unnoticed in the literature dealing with the It. Eg. and its author's provenance.

Finally, a point that deserves some consideration, even if informally, is the fact that it is possible that Egeria may have adopted some of the terms traditionally viewed as gallicisms on her way across southern Aquitaine and into the Holy Land, but she could have not borrowed so many hispanisms if her homeland and point of departure was in France.
Eucheriae. Revue Benedictine, 26, 481-84.

[8] Bynon, T. 1977. Historical linguistics. Cambridge; New York: Cambridge University Press.

[9] Campana, A. 1990. La storia della scoperta del Codice Aretino nel Carteggio Gamurrini-De Rossi. In Atti del Convegno Internazionale sulla Pereginatio Egeriae, nel centenaio della pubblicazione del Codex Aretinus 405 (già Aretinus VI, 3) (pp. 77-84). Arezzo: Accademia Petrarca Di Lettere Arti E Scienze.

[10] Corominas, J. 1954. Diccionario crítico etimológico de la lengua castellana. Berna: Editorial Francke.

[11] Devos, P. 1967. La date du voyage d'Égérie. Analecta Bollandiana, 85, 165-94.

[12] Dietz, M. 2005. Wandering monks, virgins, and pilgrims: Ascetic travel in the Mediterranean world, A.D. 300-800. University Park, Penn.: Pennsylvania State University Press.

[13] Dixon, R. M. W. 1997. The rise and fall of languages. Cambridge, U.K.; New York: Cambridge University Press.

[14] Ernout, A. 1954. Aspects du vocabulaire latin. Paris: Librairie C. Klincksieck.

[15] Férotin, D. M. 1903. Le véritable auteur de la 'Peregrinatio Silviae:' la vierge espagnole Ethéria. Revue des Questions Historiques 30, 367-397.

[16] Fonda, E. A. 1966. A síntese orgânica do Itinerarium Aetheriae. Assis, Brasil: Faculdade de Filosofia, Ciências e Letras de Assis.

[17] Gamurrini, G. F. 1887. S. Silvae peregrinatio ad loca sancta. Studi e documenti di storia e diritto, 9, 97-147 [Editio princeps].

[18] Gingras, G. E. 1970. Egeria: Diary of a pilgrimage. New York: Newman Press.

[19] Grandgent, C. H. 2002 [1907]. An Introduction to Vulgar Latin. Honolulu, Hawaii: University Press of the Pacific.

[20] Greimas, A. J. 1997. Dictionnaire de l'ancien français: Le Moyen Age. Paris: Larousse.

[21] Heraeus, W. 1929. Silviae vel potius aetheriae peregrinatio ad loca sancta ( $3^{\text {rd }}$ ed.). Heidelberg: C. Winter.

[22] Herman, J. 1967. Vulgar Latin. University Park, PA: The Pennsylvania State University.

[23] Hindley, A., Langley, F. W., and Levy, B. J. 2000. Old French-English dictionary. Cambridge, U.K.; New York, NY, USA: Cambridge University Press.

[24] Klein, H. W. 1958. Zür Latinität des Itinerarium Egeriae: Stand der Forschung und neue Erkenntnismöglichkeiten. Romanica, Festschrift für G. Rohlfs, 243-58.

[25] Kohler, K. 1884. Note sur un manuscript de la bibliothèque d'Arezzo. Bibliothèque de l'école de Chatres, 45, 141-51.

[26] Löfstedt, E. 1911. Philologischer Kommentar zur 'Peregrinatio Aetheriae' (2 ${ }^{\text {nd }}$ ed. 1936). Uppsala: Almquist \& Wiksell.

[27] Maraval, P. 1982. Égérie. Journal de voyage (Itinéraire). Paris: Les Éditions du Cerf. 
[28] Magallón García, A. I. 1993. Concordancia lematizada de los itineraries de Egeria y Antonio. Monografías de Filología Latina. Zaragoza, Spain: Universidad de Zaragoza.

[29] Meister, K. 1909. De Itinerario Aetheriae abbatissae perperam nomini S. Silvae addict. Rheinisches Museum für Philologie, 64, 337-392.

[30] Milani, C. 1969. I grecismi nell'Itinerarium Egeriae. Aevum, 43, 200-234.

[31] Muller, H. F. 1929. A chronology of Vulgar Latin. Halle an der Saale.

[32] Oorde,W. van. 1930. Lexicon Aetherianum. Rivista Clasica, 1934-1935, 187.

[33] Pountain, C. J. 2001. A history of the Spanish language through texts. London: Routledge.

[34] Rankin, R. L. 2005. The comparative method. In B. D. Joseph \& R. D. Janda (Eds.), The handbook of historical linguistics (pp. 183-212). Malden, MA: Blackwell Publishing Ltd.

[35] Rodríguez González, E. 1980 [1958]. Diccionario enciclopédico gallego-castellano. Vigo: Galaxia.

[36] Sivan, H. 1988. Who was Egeria? Piety and pilgrimage in the age of Gratian. Harvard Theological Review, 81, 39-72.

[37] Speake, J. 2003. Literature of travel and exploration: An encyclopedia. New York: Fitzroy Dearborn.

[38] Starowleyski, M. 1979. Bibliografia Egeriana. Augustinianum, 19, 297-317.

[39] Spitzer, L. 1949. The epic style of the pilgrim Aetheria. Comparative Literature, 1(3), 225-258.

[40] Swanson, D. C. 1966-67. A formal analysis of Egeria's (Silvia's) vocabulary. Glotta, 44, 177-254.

[41] Tovar, A. 1964. A research report on Vulgar Latin and its local variations. Kratylos, 9, 113-34.

[42] Trask, R. L. 2000. The dictionary of historical and comparative linguistics. Edinburgh: Edinburgh University Press.

[43] Väänänen, V. 1968 [1967]. Introdución al latín vulgar. Madrid: Editorial Gredos, S. A.

[44] Väänänen, V. 1983. Le problème de la diversification du latin. Aufstieg und Niedergang der Römischen Welt, II.29 (1), 480-506.

[45] Väänänen, V. 1985. Aspects littéraires-code scriptural vs aspects populaires-code oral. Diasystème éclaire par 1'Itinerarium Egeriae. In J. Herman (Ed.), Latin vulgaire latin tardif: Actes du $\mathrm{I}^{\mathrm{er}}$ colloque international sur le latin vulgaire et tardif (pp. 207-214). Tübingen: M. Niemeyer.

[46] Weber, C. 1989. Egeria's Norman homeland. Harvard Studies in Classical Philology, 92, 437-456.

[47] Wilkinson, J. 1981 [1971]. Egeria's travels to the holy land. Jerusalem: Ariel Pub. House.

[48] Wilson-Kastner, P. et al. 1981. A lost tradition: Women writers of the early church. Women writers of the early church. Washington, D.C.: University Press of America. 